\title{
THE ROXY LETTERS
}

By

Mary Pauline Lowry

\author{
A thesis \\ submitted in partial fulfillment \\ of the requirements for the degree of \\ Master of Fine Arts in Creative Writing \\ Boise State University
}

May 2019 
(C) 2019

Mary Pauline Lowry

ALL RIGHTS RESERVED 


\title{
DEFENSE COMMITTEE AND FINAL READING APPROVALS
}

\author{
of the thesis submitted by
}

\author{
Mary Pauline Lowry
}

Thesis Title: The Roxy Letters

Date of Final Oral Examination: $\quad 8$ March 2019

The following individuals read and discussed the thesis submitted by student Mary Pauline Lowry, and they evaluated the student's presentation and response to questions during the final oral examination. They found that the student passed the final oral examination.

Brady Udall, M.F.A.

Chair, Supervisory Committee

Mitch Wieland, M.F.A.

Member, Supervisory Committee

Joy Williams, M.F.A.

Member, Supervisory Committee

The final reading approval of the thesis was granted by Brady Udall, M.F.A., Chair of the Supervisory Committee. The thesis was approved by the Graduate College. 


\begin{abstract}
The Roxy Letters is a comedic written in letters from Roxy — an undersexed, underemployed, well-educated, and verbose twenty-something working at the deli of the flagship Whole Foods in Austin, TX - to her ex-boyfriend Everett who is living with her, but is failing to pay rent while succeeding in totally ruining her mojo!
\end{abstract}

As Roxy struggles to raise herself from her artistic, romantic, and employment slumps, she finds a new best friend in Artemis, who is a burlesque dancing, girl goddess, and huntress of men. Roxy battles with the meth heads who live next door; reluctantly tries out a sex cult focused on "Orgasmic Meditation"; and works to drive out a corporate store selling $\$ 100$ yoga tights she believes is taking the gentrification of her beloved city too far. 
TABLE OF CONTENTS

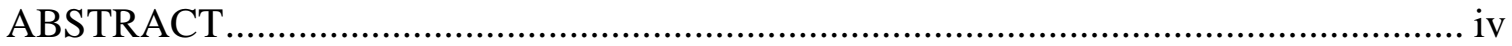

